УДК: 72.032

ББК: 85.11

DOI: $10.18688 / \mathrm{aa} 2111-01-14$

A. E. Medennikova, D. A. Karelin

\title{
On the Implication of Pictured Fortification in Roman Art
}

\section{Introduction}

The article is focused on the depictions of fortification architecture in Roman art. There are a lot of examples of images portraying whole towns and cities, as well as different details of city fortifications, fortresses, and camps.

The main goals of the study are:

- to classify the images according to the genres of art (paintings and mosaic, sculpture, models and applied art),

- to define their typology and characteristic features,

- to find out if they can show any peculiarities of Roman military architecture yet unknown to archaeologists,

- to explain the meanings of the studied depictions and distinguish the types according to the ideas and concepts they carry.

\section{Classification of the objects}

First of all, the depictions we examine can be divided into several groups. The first one is the images on coins and medals, and the depictions of cites in codices which are very similar to the aforementioned. The next two groups are numerous surviving examples of images in frescoes or mosaics which show whole cities or gates, peculiar floor mosaics with images of square wall enclosures. Furthermore, we know a lot of other sculptural depictions of fortifications: the reliefs from the Trajan's Column and the Column of Marcus Aurelius, the so-called City-Gate sarcophagi, with depictions of city walls serving as architectural backgrounds. There are also some samples of models and bronze braziers shaped as Roman fortifications. Last but not least, we should mention some objects of applied art which are represented by rare specimens of a belt buckle and a pin both shaped as city gates.

\section{Coins and Codexes}

We know quite a lot of depictions of fortifications on coins and medals. We have studied approximately 20 items made over the period since the rule of August until the $5^{\text {th }}$ century ${ }^{1}$. All the images are very simplified and quite abstract. The masonry is always shown as made of smoothly hewn plain large blocks. Generally, the pictures on medals are either axonometric views of whole cities (Fig. 1) or frontal views of gates (Fig. 2) 2 .

1 For more information see: [15; 16; 46, figs. $12-30 ; 20$, p. 43].

270 percent of the studied depictions 70 are frontal views of city gates, and 30 percent are axonometric view of a whole city. 


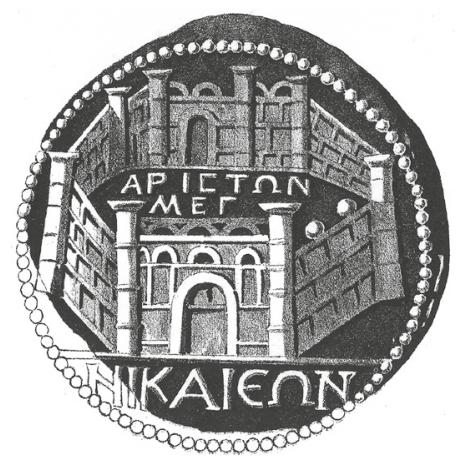

Fig. 1. City of Nicaea, brass medal, Macrianus (260-261 A. D.) [15, pp. 323-327, № 87$]$

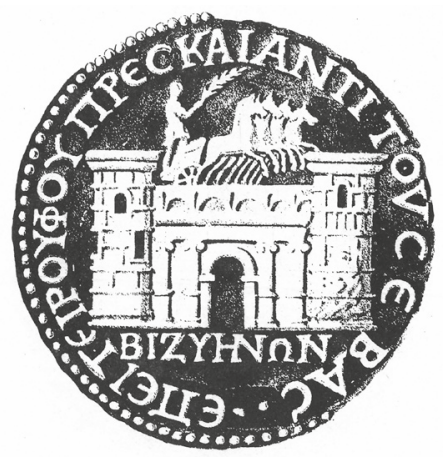

Fig. 2. Gate of Bizya, bronze medal, Hadrian (117-138 A. D.)

[15, pp. 314-317, № 84]
Looking at them, we get a rather clear idea of various architectural details, design of portals, decorative elements, and many other features of fortifications. There can be found pictures of arched galleries situated above portals [15, pp.323-327, No.87; 16, p.160, fig. 215, 161, 163 , fig. 217, 161, fig. 218] or arched galleries built within the thickness of inner walls [16, p. 161, fig. 216]. We can also get a lot of information on how the roofs of towers looked like - there are flat roofs, dome roofs, and sometimes even rotunda roofs [16, p. 124, fig. 170, 124, fig. 171]. There is also an example of a gate with a quadriga surmounting the portal [15, pp.314-317, No.83-84; 16, p. 160, fig. 213].

It is worth mentioning that quite alike images can be seen in codices as well ${ }^{3}$. The Vergilius Vaticanus (Vat.lat. $3225)^{4}$ is a manuscript of ca. $400 \mathrm{AD}$ [53; 52, pp. 271-272; 51 , p. 227; 33]. In some of its illustrations (f.35v, f.72v), we can see the depiction of cities similar to those on the coins. Other illustrations with the help of architectural images create a narrative space (f.19r, f.73v), the image of an architectural landscape (f.27r), emphasising a certain detail, for example, the entrance arch (f.13r). In Notitia Dignitatum, a manuscript that dates back to the end of the $4^{\text {th }}$ century the beginning of the $5^{\text {th }}$ century preserved as a few medieval copies, we can come across two types of illustrations: pictures of Roman fortresses and of Roman cities. The manner of depicting city walls is almost similar to that of the images on coins. The only difference is that in this case the buildings behind city walls are also portrayed. This kind of separation of objects which have different status with the help of artistic means is a frequent phenomenon for antique art. For instance, Tabula Peutingeriana [11], a map of the $4^{\text {th }}$ century, shows several variants of city images depending on their significance.

\section{Mosaics}

Murals are also a subject of interest for researchers. However, these works are rather diverse, so they can be divided into groups according to the manner of portraying cities.

Firstly, we must pay special attention to the so-called topographic mosaics, that is, floor mosaics with pictures of maps. Thus, the mosaic from Haïdra that dates back to the late $3^{\text {rd }}-$ early $4^{\text {th }}$ century, with its image of Mediterranean islands [7] is an example of depicting city walls in a sketchy, primitive way. Not every island in the picture is surrounded with walls, and in case it

See: [46, figs. 55-57, 59-64; 20, fig. 16; 44, fig. 5]. On the Vergilius Vaticanus: [52, pp. 271-272].

The digital version is available: [27]. 


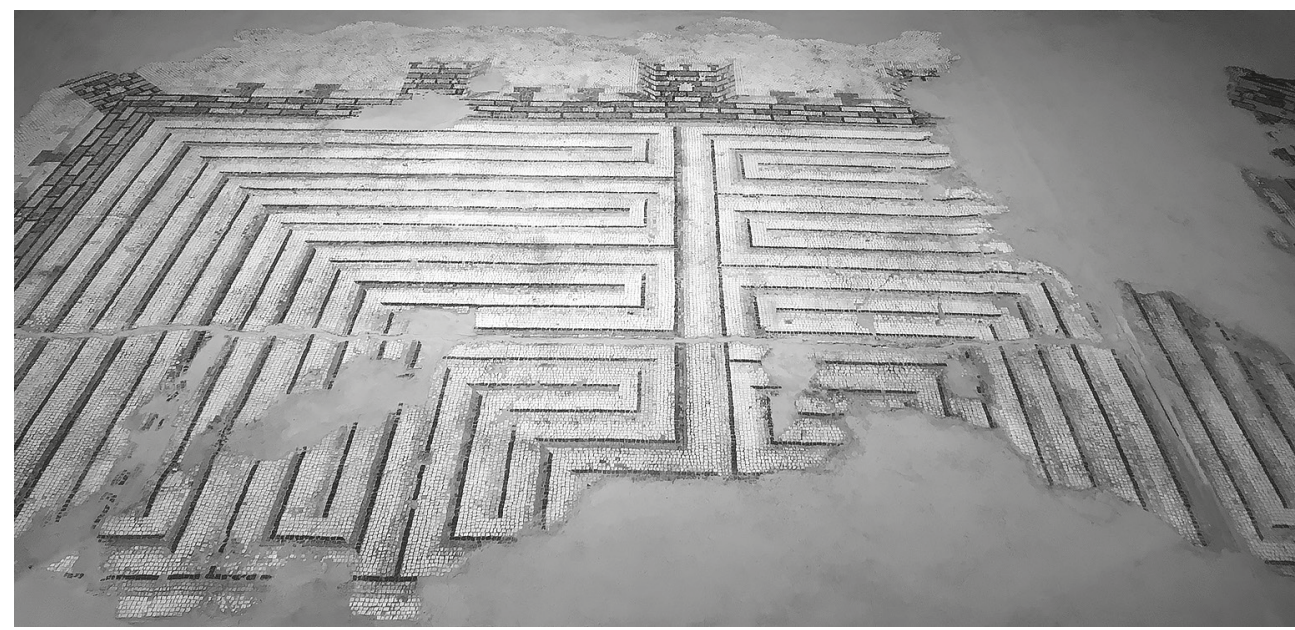

Fig. 3. Mosaic with labyrinth and city wall. Limestone, basalt and terracotta tesserae (Musei Capitolini, Centrale Montemartini exhibition center. Inv. 7892). Late Republican period (100-80 B. C.). Photo by Aleksandra Medennikova, 2019

is, the walls have no merlons [7, p. 834]. One more example is the Madaba Map [35, pp. 26-34.] of the $6^{\text {th }}$ century, which represents a kind of adaptation of the Roman Empire maps to Biblical geography. The rendering of Jerusalem is exceptional. The city is shown in a rather strange projection. The first thing we see is a cardo lined with a colonnade, with buildings on both sides; some of them can be identified [35; 30, pp. 579-581]. Other preserved segments lead to the conclusion that the presence of fortification walls in the picture was a characteristic feature of the largest and most significant cities and served as a means of demonstrating hierarchical arrangement. [35, p. 28]. The mosaic artists highlighted the city gates and defensive towers, but their main aim was to show the buildings within the city walls.

Secondly, the manner of portraying walled cities in floor or wall mosaics changes. A lot of examples of these, dating back to the $5^{\text {th }}-7^{\text {th }}$ centuries, are situated in Jordan $[35$, pp. 34-37; 30, pp. 571-589] and are very alike in style to the Madaba Map mosaics. But here, on the contrary, the focus is made on walls, accentuating a city's strength and impregnability. Artists pay special attention to the towers, sometimes we see a careful rendering of the windows as well 5 . Early Christian Roman mosaics depicting Heavenly Jerusalem and Heavenly Bethlehem ${ }^{6}$ are also quite similar to those we describe above. In Rome, the images were interpreted symbolically and closely connected with the Book of Revelation and writings of the Church Fathers [30, p. 585]. The style, a sketchy bird's eye view, reminds pictures on the coins and Jordan mosaics, but the city walls made of golden tesserae and depicting jewels are again a reference to the Book of Revelation.

5 For example, in the depiction of Jerusalem in the mosaic from the Church of St. Stephen in Umm al-Rasas.

6 For example, in the basilicas Saint Mary Major, Saint Lawrence outside the Wall, in the church of Saints Cosmas and Damian (for example, on the triumphal arch of the Basilica of Saint Mary Major that belongs to the first half of the $5^{\text {th }}$ century). 
Thirdly, floor mosaics with a labyrinth design should be recognised as a separate group. The labyrinth in this type of mosaics is enclosed by a city wall with a city gate [4]; the wall is made of massive blocks and supplemented with towers. In the centre of the picture, we can often see a scene depicting the fight between Theseus and the Minotaur. The origin of this type of walls seems to date back to the Hellenistic period [3, pp.100-101]. The walled maze iconography is documented only during the Roman period [42, p.597]. There are various examples in the western Roman globe, like the mosaic from the Capitolini Museum (Fig. 3). The two-dimensional images are intentionally simplified and may allude to a fortified city, while the foursquare structure resembles a plan of a Roman castrum. Salvetti in her essay does not exclude that the depictions of the towers and merlons are realistic, but she also mentions the symbolic meaning of the image [42, p.595].

\section{Paintings}

The landscape is a very common subject of antique fresco paintings; the iconography of many of them are generically idyllic ${ }^{7}$ or sacral idyllic landscapes ${ }^{8}$. The scenes that feature fortification walls are very rare. An image of a city encircled with a wall may appear in the depiction of a mythic episode when it is necessary for the story, as, for example, in the Daedalus and Icarus fresco from the triclinium B in the House of Sacerdos Amandus in Pompeii [6, pp. 164-166]. Here we see a mythological landscape which represents a generalized bird's eye view of a city within fortification walls with defense towers and two city gates. In addition, the fortifications can be painted if a certain city is depicted in a realistic manner, as in the fresco from Pompeii', - it shows the inner side of the walls. 'Colle Oppio Fresco' in the Baths of Trajan is another well known example [50]. This very detailed rendering of a walled city probably belongs to the whole series of urban landscapes which must have decorated the building ${ }^{10}$. Specifically due to the fact that two or more landscapes of this kind were probably painted in the same architectural space, scientists conclude that the image is realistic, and some carefully rendered buildings had to make the city recognizable for the contemporaries [50, p. 518, note 22.]. Another example which is important for illustrating the further development of this tradition in fresco paintings is a series of frescoes in the Hypogeum of the Aurelii in Rome. According to the latest research, in this case we cannot affirm that this is the depiction of a city on account of the lack of clearly portrayed fortifications ${ }^{11}$. The interesting detail here is the city gate which, however, can be shown from the inside if the participants of the scene are heading to their country residences $[12, \mathrm{p} .149 \text {, note } 70]^{20}$.

\footnotetext{
7 We can take numerous seascapes from Stabiae that are now in the National Archaeological Museum of Naples as examples, as well as the vedute from the House of M. Lucretio Frontone, the famous frescoes from the Villa of P. Fannius Sinistor in Boscoreale and the city landscape from Nero's Domus Aurea, room 85. This tradition continues up to the $2^{\text {nd }}$ century $\mathrm{AD}$, we can see a similar image in the so-called Villa Grande under the Church of Saint Sebastian outside the walls in Rome [6, pp. 294-295; 9, p. 175, note 76].

8 The columbarium at the Villa Doria Pamphili [6, pp. 167-170].

9 The depiction of the Amphitheatre of Pompeii from the House Regio I, insula 3,23 [6, p.253] from the National Archaeological Museum of Naples.

10 On the building and the location of the fresco: [50, pp. 513-519].

11 The researches tend to consider this depiction as that of the property of the Aurelii located outside the city walls [12, pp. 144-150].
} 
On the one hand, a thorough bird's eye view of the buildings shows the connection of this fresco with the tradition we have just mentioned, but, on the other hand, the idyllic character of the painting makes it possible to identify the further manner of depicted cities typical for late antiquity. The example of this tendency is the scene of Jacob's arrival to Egypt from the Hypogeum in Dino Compagni Street [10, p.466] ${ }^{21}$, where the image of the city, closed and impregnable, is akin to the mosaic images mentioned above.

\section{Sculptured reliefs}

Relief sculptures must be distinguished as a separate group. We can take the fragment of the wall from the relief of Castellum aquae [23, fig. 137] and the fragment of the wall from the Arch of Galerius [23, fig. 87] as examples, although the most significant artifacts of this group are the reliefs from the Trajan's Column and the Column of Marcus Aurelius.

All the images which belong to this group serve as the background for the depicted scenes and events. Thus, on the Arch of Septimius Severus, we can see the scene of Adventus set against the city wall, and numerous depictions of cities and camps on the Trajan's Column represent the architectural background for various scenes of the conquest of Dacia.

The reliefs of the Trajan's Column should be studied more carefully. They portray Roman camps, as well as Dacian settlements and their fortifications, both the ones loyal to Rome or hostile. It is worth mentioning that Roman camps and the cities of their allies are shown differently than the settlements of the Dacians who fought with Romans. The first ones are monumental constructions with stonewalls, although the walls, as a rule, were temporary. Inside the cities, we can see a theatre made of stone, which is hardly possible for a provincial settlement in the time of Trajan's conquest. The settlements of Romans' enemies, on the contrary, look very primitive; they are almost groups of wooden and mud-brick cabins.

We should also point out that scientists have quite different opinions on this manner of depiction. Ian Archibald Richmond [40, pp.3-6, 21-24], for instance, believed that in this way Romans portrayed city and military camp walls built of turf blocks, whereas Jon Coulston [13] and Elizabeth Thill [47, pp.28-34; 48, p. 268] consider such style of depicting fortifications and cities in general, common and familiar for the citizens of the capital, a means of imperial propaganda. In this article, we are not going to study the discussion and the arguments of the opponents $^{12}$, but we suppose that Elizabeth Thill's hypothesis is quite possible. Besides, we have already met one element of such propaganda in portraying city walls, namely the simplified and intentionally enlarged wall masonry, in the images examined before.

\section{Sarcophagi}

The so-called "City-Gate" sarcophagi (Fig. 4) are yet another group of sculptural artifacts we study. They were comprehensively described by Rina Sansoni [43], later included into the

12 The scientists give a lot of different arguments, from the fact of portraying stonemasonry tools in the scenes of construction [13, p. 145] to the interpretation of depictions of roundels, which could be details of ends of timber catwalks upon the turf walls as indicators of turf-and-timber constructions [40, pp. 53-54], also they speak about the inconsistencies and logical impossibilities in the depictions of military architecture on the column in general [13, pp. 138-139]. For more information on the discussion see: [47, pp.28-34; 40, pp. 3-6, 21-24; 13, pp. 22, 24-25, 136-139]. 


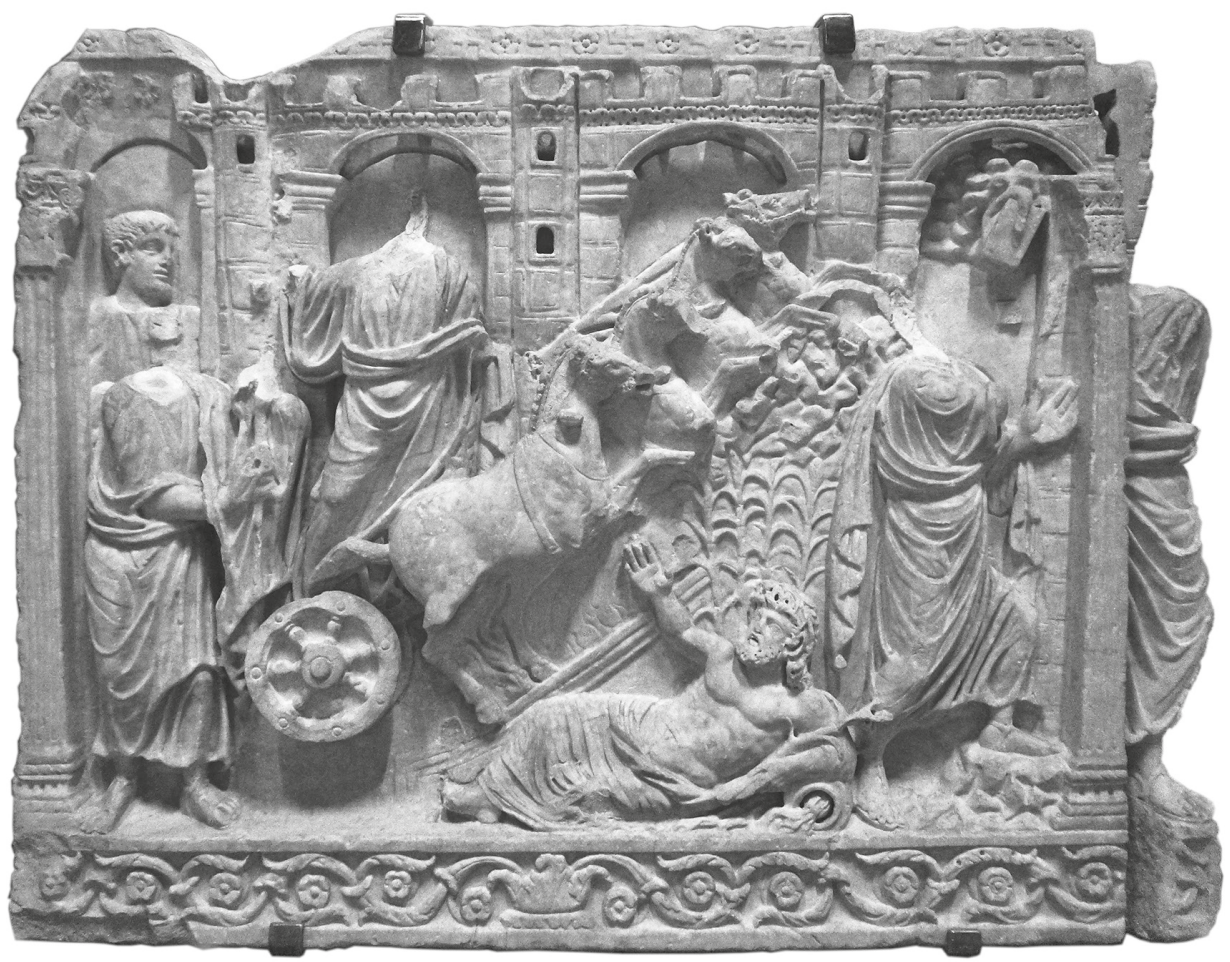

Fig. 4. Sarcophagus with Traditio legis scene. Marble. (Musée de Louvre, Inv. Ma 2980). The end of the $4^{\text {th }}$ century. Photo by Aleksandra Medennikova, 2017

Repertorium of early Christian sarcophagi by Guntram Koch [24] and analyzed by Fabrizio Bisconti [10].

They appear at the end of the $4^{\text {th }}$ century, in the decline of the classical age, and follow luxurious sarcophagi of the middle of the century. There have been discovered approximately twenty specimens of the kind; all of them were made for representatives of the upper classes of the time ${ }^{13}$. The sarcophagi, created in a Roman workshop, are of the highest quality. All four sides are decorated, that, confirms the late dating and indicates the importance of the order. Their special feature is that they are decorated with the images of city gates. We can suggest that this sort of composition originates from a widespread architectural motif, used even in pagan sarcophagi, which imitates an architectural construction in small-scale sculpture ${ }^{14}$. In early Christian sarcophagi, the image becomes more complicated and represents a city with a number of gates. However, it is not a detailed picture of city fortifications of the late antiquity

13 We can find out the names of the customers from dedicatory inscriptions. Flavius Julius Catervus [43, pp. 29-30] and Flavius Gorgonius [43, pp. 19-20] are among them.

14 For more information see: [49]. 
period, but, rather, a symbolic depiction of a border, often used in funerary $\operatorname{art}^{15}$. The city gates are quite synthesized: they have merlons and arrow slits and are made of comparatively large blocks. Their arched gateways are open and serve as the background for the figures in the foreground, but the gates do not alternate with the segments of the walls ${ }^{16}$ and become an element of design like columns, required for rhythmical separation of visual space. Here we see that the human figures are almost the same height as the gates, so the latter are used to rhythmically divide the space. In addition, the use of architectural backgrounds in these sarcophagi may be referred to the symbolic meaning that can be seen in early Christian mosaics we have analyzed. In our case it is dividing of the painting surface and accentuating the borders. In this respect the sarcophagi with city gates images approximate symbolic depictions of heavenly cities [10, pp. 465-466].

\section{Applied art}

We know a few objects of applied art, they are architectural models, i.e. braziers and an incense burner representing military architecture; we also included here a buckle and a pin shaped as a gate. There are quite many surviving braziers that imitated architectural constructions. Most of them are the rectangles standing on four beast-like legs, with a crenellated parapet on top. It seems they copy religious or sepulchral buildings rather than fortifications ${ }^{17}$. However, one of the braziers which is now in the Museum of Roman Civilization [8, fig. 7.1.2] obviously represents a small castrum with four square corner towers which, at the same time, serve as brazier legs, common merlons and a spacious courtyard.

We must also mention a terra-cotta incense burner, shaped as a Roman castrum (Ill. 16), $17 \times 19 \times 18 \mathrm{~cm}$, from the Egyptian Museum in Turin [17, p. 205, fig. 269. Inv. S. 1667]. It represents a small Roman fort with four round corner towers with vaulted roofs, which serve as its legs. This model of the fort reminds some small Roman Egypt fortresses of the late period, for instance, ain el-Labakha and Umm el-Dbadib [38].

Theoretically, we can compare this artifact with the so-called cuboid incense burners from Yemen [19] and similar samples of Ancient South Arabian culture. It is interesting to note that incense burners like that have been made there up to now [54]. They could be very simple or be shaped like some architectural construction. Such objects are especially interesting, as cultural relations between Egypt and peoples of the Arabian Peninsula were quite close. Moreover, the form of a small Roman fortress, square on plan, strongly resembles Nabataean fortifications

15 A similar motif of doors appears in pagan art too. We can take the image of ajar doors as an example that served to mark a border with the underworld such on the sarcophagus from Velletri [49, p. 405] or on the sarcophagus from the State Hermitage Museum, Inv. ГР-9630 (A. 889).

16 The depictions of walls on sarcophagi are very rare. One of them, however, is absolutely different - we can see that its sides are decorated with the images of stonework. The sarcophagus with the depiction of the deceased woman and fighting moles and cocks of the $4^{\text {th }}$ century from the National Roman Museum - the Baths of Diocletian (Inv. 65200).

17 Using such detail as a crenellated parapet is a sign of the ancient East influence [18, vol. 1, p. 68]. The element first appeared in the palace of Sargon and later was used by the Nabataeans for early tombs in Petra [31, pl. 5-19]. A crenellated parapet could be a top of Roman religious buildings in the Near East [45, pp. 104-109, 151-154], and it can also be seen in Sasanian architecture, Late Roman and probably early Muslim desert castles [18, vol. 1, pp. 68-69. figs. 3.50, 7.18]. 
which might originate from a caravanserai, widely spread in the Arabian Peninsula, so nowadays it is rather difficult to differentiate them from Roman fortresses [34, p. 116].

We know two more objects of applied art; they are a fastening buckle found in the village of Lipnik, Razgrad region, from the Regional Historical Museum Razgrad [36], and a pin, made of gilded silver and shaped as a city gate [14, fig. 4$]$. The first one dates back to the middle of the $3^{\text {rd }}$ century, and the second one probably belongs to the $3^{\text {rd }}$ century.

The fastening buckle from Abritus used to be a part of a cingula militae - a piece of ancient Roman military equipment in the form of a belt. It is made of copper, silver and gold foil in opus interrasile technique. The belt buckle consists of two parts with a plate clasp attached (Ill. 17). Each part imitates two gates with three portals each. Besides, there is a belt application (Ill. 18) shaped as a gate with two portals.

These decorative elements have many interesting details. We can see four-story towers with openings on every level, surmounted by conical roofs with spheres on top. Generally they resemble some early Christian ivories [46, figs. 68-70]. There are double arched galleries situated above the portals. In all the shown openings, the key hole decorative method was used $^{18}$. The decorative parapets also shown above do not look like real ones. In the middle of central portals of the two parts which form the plate-clasp, we can see "beneficiarius standards". The fact that the craftsman used this element may signal that the owner of the belt could be a benefeciarius consularus ${ }^{19}$.

It must be mentioned that, unlike in other images we have examined, there is no depiction of masonry here. The gates we see resemble the surviving gates in Turin (Augusta Taurinorum) and Trier (Augusta Treverorum). The fortification gates with quite a large number of openings and galleria like these are more typical for the peaceful period of time that lasted until the crisis of the middle of the $3^{\text {rd }}$ century. Later they were not built anymore.

One more specimen of a pin shaped as a city gate is now probably a part of some private collection; it was presented at the German art market [14, fig. 4]. We see the image of a gate with a double central portal, with a head above and two towers, slightly projecting from the wall, square on plan, with gable roofs. The brickwork is oversimplified, as in many images we have examined. There are arched galleries above the portals and on the upper level of the towers. In general, this gate resembles the constructions typical for the western part of the Roman Empire of the $2^{\text {nd }}$ century $\mathrm{AD}$ (approximately), before the wide spread of $\mathrm{U}$-shaped towers ${ }^{20}$.

\section{Characteristic of the depictions}

Having analyzed the examples of depictions described above, we have arrived to the following conclusions.

Firstly, we can affirm that almost in all the images, the masonry is enlarged and looks monumental. However, it is a common fact that Romans employed many different kinds of

18 For more information see: [36, pp. 156-157].

19 Another example of a bronze insignia of beneficiarius consularis, found around Razgrad [37, cat. 53]. For more information on this military rank and its symbol - the spear see: [2].

20 We can mention the gate at South Sheilds and a number of the other examples given by Paul Bidwell as the analogies for its reconstruction (Saalburg, Hasselbach) [8]. A similar, but even more simple gate can be seen in the images on the Trajan's Column (scenes 1-2) and in Aalen [29, pp. 76-81]. 
masonry, ranging from cyclopic masonry built with massive blocks to mixed techniques and brickwork built only with burnt bricks or mud bricks ${ }^{21}$ [1, pp. 191-318]. When constructing fortresses and city fortifications, especially during the late period, they very often used opus mixtum technique; walls were made of bricks or small stone blocks. One of the rare examples of a fortress built with large and smoothly hewn stone blocks is the Udruh fortress in Jordan [18, vol.2, pp.383-389, vol.3, figs. F30.1-30.5]. We suppose that this manner of depicting masonry as perfect and colossal was a means of propaganda. Here we can agree with Elizabeth Thill who considered the images of monumental and neat masonry in the reliefs of the Trajan's column in the locations where it could hardly exist in reality the effect of propaganda. There are no depictions of masonry in Tabula lliaca (which supposedly dates back to the rule of Augustus), but during the later period, beginning with the images on Augustus coins and up to the late antiquity images, masonry is portrayed in the style we described. Thus, it can be regarded as an artistic tradition formed under the influence of propaganda ${ }^{22}$.

Secondly, the examined images provide a lot of information on certain architectural details. It is particularly important, considering that most surviving Roman fortresses have only foundations left. We can see various decorative elements, parapets and a wide variety of tower roofs, from flat roofs to cupolas of complicated shapes, surmounting rotundas. This topic presents a great field for further research.

\section{Types of depicted fortifications}

The examined groups of object, classified according to the genre of art, represent several types of depicting fortifications. Although we cannot speak of realistic images (with the exception of very few examples), we managed to single out three categories which unite different artifacts.

\section{Architectural landscape}

We can include into the first group various objects: frescoes from the House of Sacerdos Amandus in Pompeii, the fight scene in the Amphitheatre of Pompeii, the 'Colle Oppio fresco' from Rome, the reliefs of the Trajan's Column, the mosaic from Haidra, the Madaba Map, the Vergilius Vaticanus (f.13r, f.19r, f.27r, f.73v). The feature that brings them all together is a high viewpoint which offers a panoramic sight of a city and makes possible to contemplate it and to examine all sorts of details ${ }^{23}$. Images of city walls are often realistic and quite accurate; however, it is not very relevant. All elements of fortifications have their own task, different for every picture. They provide the setting for a scene, as in the reliefs and manuscript, portray a certain recognizable landscape, as in the frescoes from Colle Oppio, the fight scene from the Amphitheatre and the Madaba map, or create imaginary but very convincing urban landscape, as in the fresco from the House of Sacerdos Amandus in Pompeii and Vergilius Vaticanus.

21 Generally, the latter one was used only in Egypt.

22 It is worth mentioning that there are two more images with similar stonework which have no relation to military issues. They are depictions of constructing walls [1, fig. 90; 23, fig. 1]. However, we know at least one depiction of constructing a wall from common bricks. It is the Trebius Iustis building fresco from Catacomb of Via Latina (4 ${ }^{\text {th }}$ century) [28, fig. 5].

23 The prototype of such an organisation of a narrative surface could be the Tabula Iliaca from the Capitoline Museum. 


\section{Idea of a city}

The second group includes the coinage, some illustrations in manuscripts, the mosaics from Haïdra, Jordan and Rome with the depictions of certain cities, the fresco from the Hypogeum in Dino Compagni Street, as well as the bronze braziers and the incense burner. All the images of this group show a generalized depiction of a city or a fortification. Here the viewer can see the whole city (unlike some pictures of the previous group). The city wall is one of the key elements of the image, as its aim is to emphasize the concept of safety, impregnability, and seclusion. In most cases, the accent is made on the massive wall masonry and on the city gates. We can say the same about the objects of applied art that were used in everyday life. Here the focus is also made on the walls; they separate decorative function from a practical one, and their purpose is very similar to that of the artifacts which belong to the third group.

\section{Entrance to the city}

The third group includes some coins, the sarcophagi with depictions of city gates, the Arch of Galerius in Thessaloniki, the fastening buckle from Abritus, and the fresco from the Hypogeum of the Aurelii. In these cases, the images of fortifications are reduced to the one element, that is, a city gate. This detail is not chosen randomly, it has a deep meaning, denoting the border and crossing the border. The meaning may vary slightly, sometimes marking the border between decorative function and practical function, as with the fastening buckle from Abritus, when the belt fixes a human body border and the buckle is shaped as a gate. The sarcophagi carry a very similar idea: the gate is the background and it finishes the narrative field. On the other hand, it belongs to the space where the body of the deceased rests. However, it obviously symbolizes the boundary between this world and the heavenly one. Matteo Braconi draws parallels between the fresco from from the Hypogeum of the Aurelii and the sarcophagi with the images of porta inferi $[12, \mathrm{p} .139]$. He suggests they also portray the borders of an ideal city space [12, p. 140]. Finally, we know that in Roman culture, the gate denotes the point where one could cross the sacred border of the city - the pomerium, although this is a subject for further examination.

\section{Sacred Border}

If we are going to examine the concept of border more thoroughly, we need to raise one of the most important questions of our study: what message did the Romans want to give when depicting city walls in general and what significant and sacral ideas may these images carry?

The concept of a border in Roman culture is closely connected with the notion of the pomerium $^{24}$, which is a strip of land around the city of Rome and the cities, which had the status of colonia. They could build a wall there or set up a Cippi. The Pomerium marked the border between civil and military administration; the military men had no power there and were not allowed to enter it with weapons. It was also forbidden to bury the dead inside the pomerium. One could cross it and enter the city only by going through a gate; during the rite of passage a plough was lifted (Varro, De Lingua Latina, 5.143). We will not describe the details of the

24 For more information see: $[32 ; 21 ; 5 ; 26 ; 25]$. The most significant sources are: Livy (Ab Urbe Condita, 1.44.), Varro (De Lingua Latina, 5.143), Plutarch (Questions, 27), Plutarch (Life of Romulus, 11.1-4.), Cicero (De Natura Deorum, 2.10-12). 
rite, study the etymology of the word pomerium, or discuss what exactly can be considered the pomerium $^{25}$. It is undeniable that this border meant very much to the Romans, as Romulus killed Remus for crossing it ${ }^{26}$, and Cicero tells a historical anecdote about Graccus who crossed the pomerium during the elections without taking necessary auspices, so the elections were annulled. As it seems, the only way to show this border in art was to portray a city wall or a city gate. In the numerous images we included into the group called "The idea of a city", the depicted city walls denote this same border, whereas the city gates symbolize the point where the pomerium is crossed, leaving the outer world full of dangers and entering the sacred space of the city protected by gods.

Nevertheless, it is necessary to point out that a number of floor mosaics portray a labyrinth within the rectangular countours of the city wall ${ }^{27}$. Three scientists $[41,22,42]$, regard these images as the depictions of lusus Troiae (Troy Games), a city founding ritual. They base their assumption not only on the images, but also on Vergil's text (Vergil, Aeneid, V.590-603). These lines mention Ascanius, both as a founder of Alba Longa and a person who initiated the tradition of lusus Troiae ${ }^{28}$.

This theory seems very attractive, but hard to prove, for the source gives no information on lusus Troiae as a city founding ritual, whereas the rite of creating the pomerium is described in many sources. It is quite possible that the problem of the labyrinths is still not solved and cannot be solved completely. We suggest that the city wall in this case is a kind of boundary between the labyrinth that is impossible to leave easily and the outer world, but we are not yet able to explain how the Romans comprehended the meaning and nature of this boundary.

\section{Conclusion}

There can be singled out four main types of depictions:

The first type is architectural landscapes. It includes some frescoes (for example, the 'Colle Oppio Fresco' from the Baths of Trajan and the city landscape from Hypogeum of the Aurelii), a great part of the reliefs, as well as some book illustrations.

The second type is axonometric images of cities which can very often be seen on coins, in codices, and in mosaics. We can also include here objects shaped as fortifications; for instance, a bronze brazier from the Museum of Roman Civilization or incense burners from the Egyptian museum in Turin, as, in fact, they are axonometric depictions too.

The third type is orthogonal views of city gates. We can see such images on coins, in some mosaics, and on two objects of applied art known to us.

The fourth type is floor mosaics depicting city walls that enclose a labyrinth.

25 There is no clear evidence if it is a strip of land outside city walls, or inside city walls or on both sides of city walls. Even Roman sources explain it differently. For example, Varro says it is an area of ground behind the city wall, Livius says it was situated on both sides of the wall, and Plutarch says that the pomerium is the city wall itself, with no land adjacent.

26 Plutarch (Life of Romulus, 11.1-4).

27 It is curious that while various sources usually describe a multicursal model of labyrinth, we can see an unicursal model in images. For more information see: [39, pp. 39-63, esp.40].

28 "This game and mode of march Ascanius, / when Alba Longa's bastions proudly rose" (Trans. by Theodore C. Williams). Original text of lines 596-597 in Latin: "hunc morem cursus atque haec certamina primus Ascanius / Longam muris cum cingeret Albam". 
In most depictions, the stonework is shown in the same special manner: an exaggerated stonework of huge rectangular blocks. The Romans used a wide variety of masonry types in building practice, but we do not see it in the images we examine.

The depictions reveal many architectural peculiarities of Roman military architecture, unknown to archaeologists, which must be a subject for further research.

There can be distinguished three essential meanings of the studied depictions.

The first one is the depiction of the architectural landscape itself. It can be seen in monumental art and in miniatures. The principal aim of this type of images is to create an ideal landscape or to form the space for scenes.

The second meaning is the representation of the idea of a city. The artifacts are mostly coinage, book illustrations and wall mosaics. Here a city is shown in general; a special attention is paid to the city walls that emphasize its safety and seclusion.

The last one is the depiction of the city entrance, which symbolizes the passage between two realities. This group includes various objects such as coins, sarcophagi, mosaics, and works of applied $\operatorname{art}^{29}$. The essential meaning of that is the sacral border (the pomerium mainly) which is the projection of the beliefs of the ancient.

\section{Acknowledgements}

We are very grateful to the director of the Regional Historical Museum Razgrad Galena Radoslavova for the photos of the fastening buckle from Abritus and her permission to publish them. We also would like to thank Nadezda Nalimova and Enrico Pizzoli for advice and various assistance.

\section{References}

1. Adam J.-P. Roman Building: Materials and Techniques. London, New York, Routledge Publ., 1999. 360 p.

2. Alföldi A. Hasta - Summa Imperii. The Spear as Embodiment of Sovereignty in Rome. American Journal of Archaeology, 1959, vol. 63, pp. 1-27.

3. Alves F. Aspectos dea relações entre o mosaico e a arquitectura no mundo romano. Iconografia e iconologia do tema da muralha no mosaico romano. Tese de Doutoramento em História da Arte da Antiguidade, Universidade Nova de Lisboa, 2010. 254 p. (in Portuguese).

4. Alves F. O. O labirinto no mosaico pavimental romano. Revista do Instituto de História da Arte, 2007, no. 3, pp. 40-51 (in Portuguese).

5. Antaya R. The Etymology of Pomerium. The American Journal of Philology, 1980, vol. 101, pp. 184-189.

6. Baldassare I.; Pontrandolfo A.; Rouveret A.; Salvadori M. (eds.) Pittura Romana. Milan, Federico Motta Editore Publ., 2006. 239 p. (in Italian).

7. Bejaoui F. Îles et villes de la Méditerranée sur une mosaïque d'Ammaedara (Haïdra en Tunisie). Comptes rendus des séances de l'Académie des Inscriptions et Belles-Lettres, 1997, vol. 141, no. 3, pp. 825-858 (in French).

8. Bidwell P.; Miket R.; Ford B. The Reconstruction of a Gate at the Roman Fort of South Shields. Bidwell P.; Miket R.; Ford B. (eds.) Portae cum turribus: Studies of Roman Fort Gates. Oxford, Archaeopress Publ., 1989, pp. 155-231.

9. Bisconti F. (ed.). Le pitture delle catacombe romane. Restauri e interpretazioni. Todi, Tau Editrice Publ., 2010. 261 p. (in Italian).

29 The architectural models could belong both to the second and the third group. However, they could have no specific meaning connected to an image of the city. That's because we preferred not to include these objects to any group. 
10. Bisconti F. I sarcofagi "a porte di città": prototipi antichi ed esiti paleocristiani. Quintavalle A.C. (ed.). Medioevo: la chiesa e il palazzo. Atti del convegno internazionale di studi, Parma, $20-24$ settembre 2005. Milano, Mondadori Electa Publ., 2007, pp.456-467 (in Italian).

11. Bosio L. la Tabula Peutingeriana: una descrizione pittorica del mondo antico. Rimini, Maggioli Publ., 1983. 234 p. (in Italian).

12. Braconi M. Il cavaliere, il retore, la villa. Le architetture ultraterrene degli Aureli tra simbolo, rito e autorappresentazione. Bisconti F. (ed.). L'ipogeo degli Aureli in viale Manzoni. Restauri, tutela, valorizzazione e aggiornamenti interpretativi. Todi, Tau Editrice Publ., 2011, pp. 135-165 (in Italian).

13. Coulston J.C. Trajan's Column: the Sculpting and Relief Content of a Roman Propaganda Monument, Ph.D. Thesis. Newcastle upon Tyne, The University of Newcastle upon Tyne, 1988. xv, 354 p.

14. Ćurčić S. Architecture as Icon. Ćurčić S.; Hadjitryphonos E. (eds.) Architecture as Icon: Perception and Representation of Architecture in Byzantine Art. New Haven, London, Princenton University Art Museum Publ., 2010, pp. 1-37.

15. Donaldson T.L. Ancient Architecture on Greek and Roman Coins and Medals. Chicago, Argonaut Publ., 1966. xxxi, $361 \mathrm{p}$.

16. Elkins N. Monuments in Miniature: Architecture on Roman Coinage. New York, The American Numismatics Society Publ., 2015. ix, 230 p.

17. Greco C. et al. Museo Egizio. Modena, Franco Cosimo Panini Editore; Torino, Fondazione Museo delle antichità egizie di Torino Publ., 2015. 265 p. (in Italian).

18. Gregory S. Roman Military Architecture on the Eastern Frontier. Amsterdam, A. M. Hakkert Publ., Vol.1. 1995. xxvii, 302 p.; Vol. 2. 1996. 457 p.; Vol.3. 1997. Ill.

19. Incense-burner, The British Museum official site. Available at: https://www.britishmuseum.org/collection/ object/W_1915-0710-5 (accessed 31 January 2021).

20. Johnson S. Late Roman Fortifications. London, B. T. Batsford Publ., 1983. 315 p.

21. Kent R.G. The Etymological Meaning of Pomerium. Transactions and Proceedings of the American Philological Association, 1913, vol. 44, pp. 19-24.

22. Kern H. Through the Labyrinth: Designs and Meanings over 5,000 Years. Munich, New York, Prestel Publ., 2000. 360 p.

23. Kidd A. B. Imaginibus vel Simulacris: Depicting Urban Landscapes and Architecture in Roman Antiquity, Ph.D. Thesis. New York, New York University, 2018. xxviii, 388 p.

24. Koch G. Frühchristliche Sarkophage. München, C. H. Beck Publ., 2000. 665 p. (in German).

25. Koortbojian M. Crossing the Pomerium: The Boundaries of Political, Religious, and Military Institutions from Caesar to Constantine. Princeton, Princeton University Press Publ., 2020. xix, 228 p.

26. Liou-Gille B. Le pomerium. Museum Helveticum, 1993, vol.50, pp.94-106 (in French).

27. Manuscript - Vat.lat.3225. Digital Vatican Library. Available at: https://digi.vatlib.it/mss/detail/Vat. lat.3225 (accessed 31 January 2021).

28. Marucchi O. L'ipogèo sepolcrale di Trebio Giusto, recentemente scoperto sulla Via Latina, e proposta di spiegazione gnostica delle due pitture. Nuovo Bullettino di Archeologia Cristiana, 1911, vol.17, pp.20935 (in Italian).

29. Matešić S.; Sommer C. S. (eds.). At the Edge of the Roman Empire: Tours along the Limes in Southern Germany. Mainz, Nünnerich-Asmus Verlag \& Media Publ., 2015. 239 p.

30. Mazzoleni D. Gerusalemme e Betlemme nelle mosaici di Giordania: rappresentazioni reali o simboliche? Cavalcanti E. (ed.). Il De civitate Dei. L'opera, le interpretazioni, l'influsso. Roma; Frieburg; Wien, Herder Publ., 1996, pp.589-611 (in Italian).

31. McKenzie J. The Architecture of Petra. Oxford, New York, Oxford University Press Publ., 1990. xxii, 209 p.

32. Mommsen Th. Der Begriff des Pomerium. Hermes, 1886, vol. 10, pp. 40-50 (in German).

33. Nolhac P. de. Le Virgile de Vatican et ses peintures. Paris, Imprimerie Nationale Publ., 1917. 111 p. (in French).

34. Parker S. T. Romans and Saracens: A History of the Arabian Frontier. Winona Lake, The American School of Oriental Research Publ., 1986. xiii, 247 p.

35. Piccirillo M. The Mosaics of Jordan. Amman, American Center of Oriental Research Publ., 1993. 383 p.

36. Radoslavova G. Kolanna garnitura ot grob na Beneficiarius Consularis ot selo Lipnik, Razgradska obshhina. Dzanev G. (ed.). Izvestija na Rim - Razgrad (Reports on Rome - Razgrad). Razgrad, Faber Publ., 2014, pp. 152-161 (in Bulgarian).

37. Radoslavova G.; Dzanev G.; Nikolov N. The Battle at Abritus in AD 251: Written Sources, Archaeological and Numismatic Data. Archaeologia Bulgarica, 2011, vol. 15, pp. 23-49. 
38. Reddé M. Sites militaries romains de l'oasis de Kharga. Bulletin de l'Institut français d'archéologie orientale, 1999, vol. 99, pp. 377-396 (in French).

39. Reed Doob P. The Idea of the Labyrinth from Classical Antiquity through the Middle Ages. Ithaca, Cornell University Press Publ., 1990. xviii, 355 p.

40. Richmond I. A. Trajan's Army on Trajan's Column. London, British School at Rome Publ., 1982. x, 56 p.

41. Rykwert J. The Idea of a Town: The Anthropology of Urban Form in Rome, Italy and The Ancient World. Cambridge, Mass, MIT Press Publ., 1988. 242 p.

42. Salvetti C. La rappresentazione del labirinto e della cinta muraria in un mosaico romano da San Giovanni in Laterano. Rendiconti della Pontificia Accademia Romana di Archeologia, 2015-2016, vol. 88, pp. 587-609 (in Italian).

43. Sansoni R. I sarcofagi paleocristiani a porte di città. Bologna, Casa editrice prof. Riccardo Patron Publ., 1969. 117 p. (in Italian).

44. Saradi H. Space in Byzantine Thought. Curčić S.; Hadjitryphonos E. (eds.). Architecture as Icon: Perception and Representation of Architecture in Byzantine Art. New Haven, London, Princenton University Art Museum Publ., 2010, pp. 73-111.

45. Segal A. Temples and Sanctuaries in the Roman East: Religious Architecture in Syria, Iudaea/Palaestina and Provincia Arabia. Oxford, Oxbow Books Publ., 2013. x, 380 p.

46. Smith E. B. Architectural Symbolism of Imperial Rome and the Middle Ages. Princeton, New Jersey, Princeton University Press Publ., 1956. ix, 219 p.

47. Thill E. Civilization under Construction: Depictions of Architecture on the Column of Trajan. American Journal of Archaeology, 2010, vol. 114, pp. 27-43.

48. Thill E. Don't Confuse Us with the Facts Visualizing the Frontier in the Capital City. Sommer S.; Matešić S. (eds.). Limes XXIII: Proceedings of the 23 ${ }^{\text {rd }}$ International Congress of Roman Frontier Studies, Ingolstadt 2015. Mainz, Nünnerich-Asmus Verlag, 2018, pp. 265-272.

49. Thomas E. 'Houses of the Dead'? Columnar Sarcophagi as 'Micro-Architecture'. Elsner J.; Huskinson J. (eds.). Life, Death and Representation. New York, De Gruyter Publ., 2011. 446 p.

50. Volpe R. Paesaggi urbani tra Oppio e Fagutal. Mélanges de l'École française de Rome. Antiquité, vol.112, no. 2, 2000, pp. 511-556 (in Italian).

51. Weitzmann K. (ed.). Age of Spirituality. Late Antique and Early Christian Art, Third to Seventh Century. Catalogue of the Exhibition at the Metropolitan Museum of Art. New York, The Metropolitan Museum of Art Publ., 1979. 735 p.

52. Weitzmann K. Book Illustration in the $4^{\text {th }}$ Century. Tradition and Innovation. Akten des VII. Internationalen Kongresses für christliche Archäologie, Trier, 5-11 September 1965. Vatican City, Pontificio istituto di archeologia cristiana Publ., Berlin, Deutsches Archäologische Institut Publ., 1969, pp. 257-282.

53. Wright D. H. The Vatican Vergil. A Masterpiece of Late Antique Art. Berkeley, University of California Press Publ., 1993. 141 p.

54. Zimmerle W.G. From History to Heritage: the Arabian Incense Burner. Fromherz A.J. (ed.). The Gulf in World History: Arabia at the Global Crossroads. Edinburgh, Edinburgh University Press Publ., 2018, pp. 295-312.

Title. On the Implication of Pictured Fortification in Roman Art

Author. Medennikova, Alexandra Evgenievna - doctoral student. Pontificio Istituto di Archeologia Cristiana, Via Napoleone III, 1, 00185 Roma, Italia. alexandra.medennikova@gmail.com OCRID: 0000-0001-8725$158 \mathrm{X}$

Karelin, Dmitry Alexeevich - Ph. D., professor. Moscow Institute of Architecture (State Academy) (MARCHI), Rozhdestvenka, 11/4, 107031 Moscow, Russian Federation. dmitry.a.karelin@gmail.com OCRID: 00000002-0846-0381

Abstract. There are many examples of depictions of city walls, fortresses, and military camps in Roman art. The goals of the study are to classify the examined depictions, to reveal the peculiarities and architectural details of fortifications, which are little-known according to archaeological data, and to analyze the features of the studied depictions. They can be divided into several types: images on coins, medals, and in codices; frescoes or mosaics; objects of applied art and architectural models; sculptural reliefs. The studied images show many architectural peculiarities of Roman military architecture unknown to archaeology and have common features. For example, the masonry is usually shown in the same manner: it is monumental and made of huge rectangular 
blocks. The article singles out three main meanings of the examined images: the architectural landscape, the idea of a city (urbs) and the depiction of sacral borders (the pomerium and others).

Keywords: wall paintings, fresco, mosaic, coins, models, wall, tower, fortress, military camp, gate, Roman art, architectural backgrounds

Название статьи. О значении изображений крепостной архитектуры в римском искусстве

Сведения об авторах. Меденникова Александра Евгеньевна - аспирант, Папский Институт Христианской Археологии, ул. Наполеоне III, 1, Рим, Италия, 00185. alexandra.medennikova@gmail.com OCRID: 0000-0001-8725-158X

Карелин Дмитрий Алексеевич - кандидат искусствоведения, профессор. Московский архитектурный институт (государственная академия) (МАРХИ), ул. Рождественка, 11/4, Москва, Российская Федерация, 107031. dmitry.a.karelin@gmail.com OCRID: 0000-0002-0846-0381

Аннотация. Существует немало изображений городских стен, крепостей и лагерей в римском искусстве. Задачи исследования заключаются в попытке классифицировать изученные изображения, выявить малоизвестные по материалам археологии архитектурные особенности и элементы, а также проанализировать их черты. Изученные изображения можно разделить на несколько типов. Это изображения на монетах и медалях и из кодексов; фрески и мозаики; предметы прикладного искусства и модели крепостей; скульптурные рельефы. Рассмотренные нами изображения содержат значительную информацию о деталях, не известных по археологическим исследованиям, и имеют ряд общих черт, например, гипертрофированно и обобщённо показанную каменную кладку. Можно выделить три основных смысловых значения изученных изображений: архитектурный пейзаж, изображение идеи города (urbs) и изображение границы (померий и другие).

Ключевые слова: живопись, фрески, мозаики, монеты, модели, стена, башня, крепость, лагерь, ворота, римское искусство, изображённая архитектура 


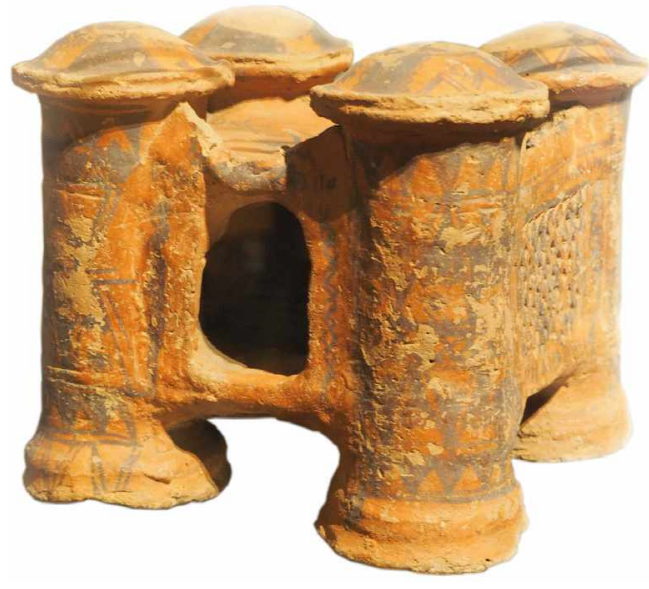

Ill. 16. Incense burner in form of Roman castrum. Terracota (Egyptian museum in Turin. Inv. S. 1667) Roman period (30 B. C. - 395 A. D.). Photo by Irina Kulikova, 2015

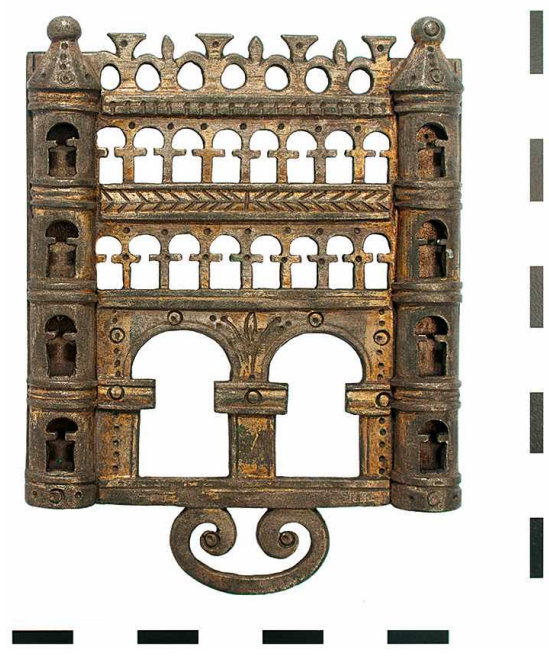

Ill. 18. Belt application. Opus interrasile.

Copper, silver and gold foil (Regional Historical Museum Razgrad). Mid $3^{\text {rd }}$. Courtesy by Galena Radoslavova. See p. 169 [36, Ill. 7a]

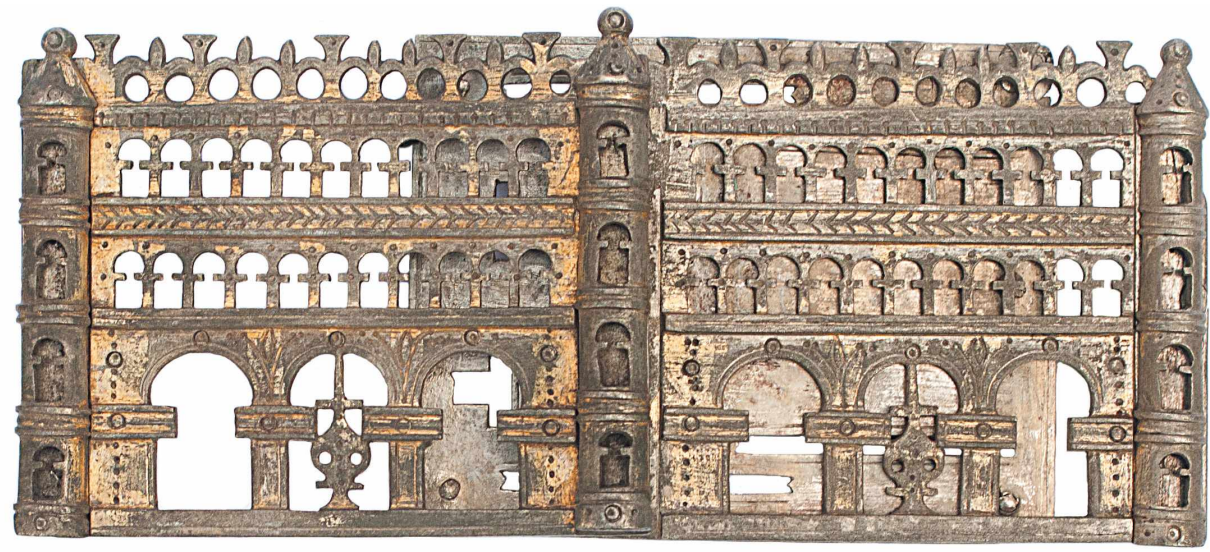

Ill. 17. Fastening buckle. Opus interrasile. Copper, silver and gold foil (Regional Historical Museum Razgrad). Mid $3^{\text {rd }}$. Courtesy by Galena Radoslavova. See p. 169 [36, Ill. 4a] 